\title{
Le discours juridique en France et en Angleterre
}

Convergences et spécificités

\section{Bernard Galonnier}

\section{(2) OpenEdition}

Journals

Édition électronique

URL : http://journals.openedition.org/asp/3245

DOI : $10.4000 /$ asp.3245

ISSN : 2108-6354

Éditeur

Groupe d'étude et de recherche en anglais de spécialité

\section{Édition imprimée}

Date de publication : 1 décembre 1997

Pagination : 427-438

ISSN : 1246-8185

Référence électronique

Bernard Galonnier, «Le discours juridique en France et en Angleterre », ASp [En ligne], 15-18| 1997, mis en ligne le 26 novembre 2012, consulté le 19 avril 2019. URL : http://journals.openedition.org/ asp/3245; DOI : 10.4000/asp.3245

Ce document a été généré automatiquement le 19 avril 2019

Tous droits réservés 


\title{
Le discours juridique en France et en Angleterre
}

Convergences et spécificités

\author{
Bernard Galonnier
}

\section{Introduction}

1 Le discours juridique présente des traits distinctifs qui semblent dépasser les frontières ; c'est ainsi que de part et d'autre de la Manche on note le recours à un jargon spécifique ainsi que l'emploi d'un registre élevé. En outre, en France comme en Angleterre certains termes prennent une acception particulière dans la langue du droit. Enfin, la présence de termes français contribue dans une certaine mesure à rapprocher ces deux langues de spécialité.

2 Cependant, pour des raisons historiques, le discours juridique anglais se singularise non seulement par des concepts qui lui sont propres, mais encore par une personnalisation du discours qui rend compte du rôle du juge dans la common law. C'est ainsi que dans leurs jugements les magistrats anglais, loin d'être concis et synthétiques comme leurs confrères français, se montrent fort prolixes et ne craignent pas de faire preuve d'humour et de recourir à une langue imagée. Cette manière si singulière de s'exprimer dans un tel contexte est révélatrice d'une approche pragmatique propre à la common law et d'un raisonnement analogique qui s'oppose à la démarche déductive que l'on associe au droit romain.

3 Cet article se propose de mettre en relief les raisons historiques et culturelles qui rendent compte des conventions et des particularismes propres à la langue du droit anglais telle qu'elle est employée par les magistrats dans leurs comptes rendus de décisions de justice ou law reports. 


\section{Points de convergence}

\subsection{Recours au jargon} constamment employés de préférence à "entre autres choses » et "à première vue ». Comme en France, le respect de la tradition et des usages explique le recours à des formules figées ; c'est ainsi que le juge anglais désigne son éminent confrère en parlant de my learned friend:

The reason so cogently deployed in the speech of my noble and learned friend.

On the evidence before the learned judge...

Par ailleurs, un certain nombre de termes obsolètes subsistent dans l'anglais juridique. Parmi les plus répandus citons :

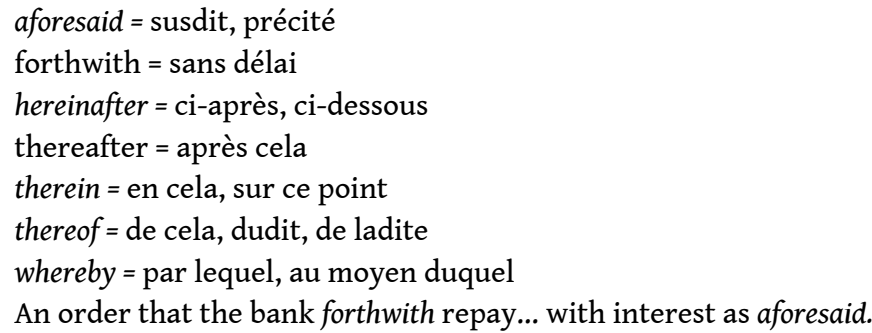

6 L'emploi de formules archaïques et figées a pour objet de donner aux jugements un caractère intemporel ; la permanence des principes fondamentaux de la justice et leur universalité trouvent leur illustration dans l'emploi de termes qui ont traversé les siècles et ont résisté aux aléas des vicissitudes humaines. La manière codifiée d'exprimer l'accord ou le désaccord ( I would respectfully join issue with my learned friend", "With the utmost respect I cannot accept...")permet de rappeler au locuteur son appartenance à une corporation et de susciter ainsi sa bienveillance.

\subsection{Un registre élevé}

7 À l'image de leurs confrères français, les juristes anglais font preuve de recherche et de formalisme dans leur manière de s'exprimer. Les prépositions appartiennent à un registre élevé :

The government amendment was carried in lieu of the Lords'amendment.

The period pending the visitor's determination. Save est employé à la place de except et absent est utilisé de préférence à without ou in the absence of:

Save for the purpose of classification...

Absent any medical opinion...

What is compendiously called the right of silence...

Thenceforward it was to be taken...

There was nothing novel...

Section 15 is not otiose.

Eleemosynary foundations such as schools...

A kind of proleptic criminal trial. 
Pour ce qui est des noms, commencement ou inception sont employés de préférence à beginning. Ajoutons que la nominalisation est un des traits distinctifs de l'anglais du droit. Ainsi, dans les law reports le début ou la fin d'une action sont exprimés de la manière suivante :

...demands the resumption of the action before the court.

The present dispute arose because of the discontinuance of an interim agreement.

11 Un tel registre, associé à une syntaxe élaborée où abondent subjonctifs et such... as employé comme pronom relatif, ne peut manquer de souligner, comme c'est le cas en France, la dignité d'une institution vénérable ainsi que la permanence des principes qui la fondent.

\subsection{Des acceptions spécifiques}

Tout comme en droit français, certains mots de la langue usuelle prennent dans la langue de spécialité une acception particulière. L'emploi de termes usuels dans une acception spécifique est une constante de la langue du droit anglais. Voici quelques exemples particulièrement significatifs :

magistrates'clerk ou justices'clerk = conseil attaché aux juges non professionnels

of course, nowadays a justices'clerk will not withdraw with the justices.

Dans la mesure où les magistrates sont des non-professionnels, il a été nécessaire de leur adjoindre des clerks qui sont des avocats ayant au moins cinq ans de pratique. Ils ont pour mission de conseiller le juge sur des points de droit et, en outre, ils remplissent aussi des tâches administratives en dressant les procès-verbaux de témoignages et en préparant les assignations et mandats délivrés par le tribunal.

contempt of court = outrage à la cour, entrave à la bonne administration de la justice

The court is given discretion to treat silence as if it were contempt.

cond coupable de contempt of court quiconque refuse de soumettre au tribunal les pièces du dossier. De plus, tout journaliste qui publie des commentaires susceptibles de porter atteinte au déroulement équitable du procès et de préjuger de l'issue de l'affaire est passible de poursuites pour contempt.

false imprisonment = entrave à la liberté de circulation

After being forbidden access to the footpath the plaintiff sued in false imprisonment.

Un promeneur peut faire valoir qu'il a été victime de false imprisonment si l'autorité municipale lui refuse de manière arbitraire l'accès au chemin qu'il emprunte habituellement pour se rendre à son domicile. En outre, une arrestation légale peut se transformer en false imprisonment si les motifs de l'arrestation ne sont pas précisés dans des délais raisonnables à la personne soupçonnée.

frustration = impossibilité d'exécution de contrat

As the new statute made performance of the covenant impossible the contract was

considered as frustrated by subsequent impossibility.

17 En cas de force majeure, un contrat peut être considéré comme éteint par impossibilité d'exécution. Selon le principe de la common law, toute perte était à la charge de celui qui la subissait. Depuis la loi de 1943 (Law Reform, Frustrated Contracts, Act 1943), la règle a été assouplie et la partie lésée peut obtenir le remboursement des valuable benefits accordés au cocontractant avant qu'un cas de force majeure ait empêché ce dernier de remplir ses obligations. 
repudiation $=$ dénonciation unilatérale d'un contrat

The contract has been repudiated by the company on the ground of fraud.

18 Si une des parties au contrat manque à ses obligations et si ce manquement affecte une clause fondamentale, l'autre partie peut révoquer unilatéralement ce contrat. En droit français lorsqu'un cocontractant s'estimant lésé désire mettre fin unilatéralement au contrat il doit, en l'absence d'une clause résolutoire dûment stipulée, en faire prononcer la résolution par le tribunal. En revanche, le droit anglais dans un souci de pragmatisme estime que le contrat peut prendre fin dès que le comportement d'une des parties permet de conclure qu'elle n'a pas l'intention de remplir ses obligations. En fonction de l'évolution des marchés financiers, la partie lésée peut, soit réclamer aussitôt des dommages-intérêts, soit attendre l'échéance du terme.

Rappelons qu'en droit français également bien des termes de la langue courante (cause, conclusion, dispositif, exception, moyen...) revêtent un sens particulier dans un contexte juridique.

\subsection{Présence de termes français dans le droit anglais}

Un dernier trait contribue à rapprocher le discours juridique des deux pays ; il s'agit de la présence non négligeable de termes français dans le droit anglais. C'est ainsi que l'on parle de cause célèbre, de profits à prendre ouencore de estate pur autre vie (intérêts qu'a une personne $\mathrm{X}$ sur un bien durant l'existence d'une personne $\mathrm{Y}$ appelée cestui que vie).

21 La présence de termes français est moins surprenante qu'il n'y paraît à première vue si l'on se souvient qu'à partir de la conquête normande de 1066 le français fut la langue utilisée dans les cours royales de justice. Les juges itinérants chargés par Guillaume le Conquérant et ses successeurs de recueillir les coutumes du pays et de rendre la justice au nom du roi ne connaissaient que le français ; cette langue évolua peu à peu au contact du peuple qui parlait saxon et des ecclésiastiques qui utilisaient le latin. C'est la synthèse de ces trois influences qui constitue ce que l'on a appelé la Law French et dont l'usage ne fut définitivement interdit par des textes de loi qu'en 1733 et 1735 . Le fameux juge du dixseptième siècle, Sir Edward Coke (1552-1634) assurait que la Law French devait être employée de crainte que les profanes n'aient la présomption de lire des documents qu'ils pourraient interpréter de manière erronée :

Lest the unlearned by bare reading without right understanding might suck out errors and trusting to their conceit, might endanger themselves.

22 Pour ce qui est de cause célèbre, son emploi régulier s'explique par le fait que dans un système de common law le juge recherche constamment des affaires anciennes qui font autorité :

The case was revealed to be a cause célèbre in which the great issue (of immense public interest) related to the power to levy taxes.

Une femme non mariée s'appelle feme sole. Le terme s'étend à une veuve, une divorcée ou encore à une femme dont le mariage a fait l'objet d'une annulation :

The wife may sue and be sued in tort as a feme sole, and the husband is no longer

liable for her torts by reason only of being her husband.

Dans l'exemple précédent, nous rencontrons le terme tort qui désigne le vaste domaine de la responsabilité civile. Ce terme depuis longtemps adopté par la langue du droit anglais n'est certes plus perçu comme étranger; toutefois, il n'en demeure pas moins vrai que c'est bien un mot d'origine française qui désigne un civil wrong, c'est-à-dire une atteinte à 
un droit civil non contractuel qui entraîne la responsabilité de son auteur. Tout manquement à ce type d'obligation prévu par la loi peut faire l'objet de poursuites en dommages-intérêts. moins vrai que le discours juridique anglais, dans le fond comme dans la forme, présente des traits distinctifs qui lui confèrent un caractère unique. Non seulement le droit anglais a élaboré des concepts qui lui sont propres, mais de plus les juges de common law ont su donner à leur discours une tonalité personnelle non dépourvue d'humour ainsi qu'un caractère concret qui témoignent d'une démarche qui se veut empirique et inductive.

\subsection{Des concepts spécifiques}

31 Nombreux sont les concepts propres au droit anglais, qu'il s'agisse de l'equity ou des trusts. Deux autres termes associés respectivement au droit des contrats et à celui de la 
propriété méritent que l'on s'attarde sur leur signification et sur leur portée. Il s'agit de consideration et de estate.

consideration = contrepartie fournie (executed) ou promise (executory) en échange d'un engagement

All the issued share capital was acquired for a consideration of approximately $£ 420 \mathrm{~m}$. Later the plaintiff brought an action to recover the deposit as on a failure of consideration.

En droit anglais, il s'agit là d'un élément essentiel à la formation d'un contrat autre qu'un contrat formel (deed). Le droit anglais reconnaît les marchés dûment conclus et non les simples promesses. Celui à qui une promesse a été faite doit donner une contrepartie s'il veut s'assurer que l'autre partie tiendra ses engagements. Un tel principe a été énoncé de manière imagée dès 1602 dans une affaire d'importance historique connue sous le nom de Pinnel's Case :

Payment of a lesser sum on the day cannot be any satisfaction for the whole, but a change in time or mode of payment or the addition by the debtor of a tomtit or canary or the like will suffice to constitute consideration for the creditor's promise to forgo his debt.

La contrepartie peut consister en une somme d'argent, un avantage accordé ou un renoncement à agir.

es juges s'efforcent d'inscrire ce terme dans un cadre précis, mais il arrive que certains d'entre eux proposent une interprétation extensive de la notion de consideration. À une époque où il n'était pas possible d'engager des poursuites pour déclarations erronées (misrepresentation), le juge trouva cependant moyen d'accorder réparation à un plaignant qui avait fait de mauvais placements à la suite des déclarations inconsidérées d'un expert en investissements. Le magistrat considéra en effet qu'il y avait entre les parties une relation contractuelle car la victime avait fourni à l'expert une consideration en échange de ses conseils financiers ; la consideration consistait dans le fait que l'expert était autorisé à faire état dans une brochure publicitaire de la demande de conseils en investissements émanant du plaignant. Ainsi le défendeur avait obtenu un avantage réel.

estate $=$ droit exercé sur une propriété immobilière

A legal estate in land may be created, extinguished or disposed of only by deed.

La notion d'estate traduit la nette opposition qui existe entre les concepts français et anglais en matière de propriété immobilière. Le droit français, hostile à tout démembrement du droit de propriété, est fondé sur le principe que le propriétaire en tant que titulaire unique concentre entre ses mains la totalité des pouvoirs et exerce des droits absolus.

Il en va tout autrement en Angleterre où seul le monarque est censé concentrer entre ses mains la totalité des attributs d'une propriété ; dès lors, une personne ne peut exercer qu'un ensemble d'intérêts plus ou moins importants que l'on nomme estates.

Un legal estate se subdivise donc entre:

freehold = bien immeuble tenu en propriété absolue par un freeholder

leasehold = bien-fonds loué à bail à un leaseholder

38 Entre les statuts de freeholder et de leaseholder il existe moins une différence de nature qu'une différence de degré, en particulier du fait de l'octroi fréquent (surtout à Londres) de baux de longue durée ( 99 ans) appelés long term leases.

Rappelons enfin l'autre sens juridique de estate: succession, patrimoine (estate duties $=$ droits de succession). 


\subsection{Personnalisation du discours juridique}

À la différence des jugements français, les jugements anglais loin d'être synthétiques sont au contraire fort prolixes. La raison en est la prise en compte des opinions minoritaires ainsi que la nécessité pour le juge de common law de se référer aux précédents et de justifier l'élaboration de la règle de droit. Pour le juge anglais, le moi n'est pas haïssable ; son implication est manifeste comme en témoigne l'emploi constant du pronom personnel de la première personne $I$ :

I then ask myself...

I digress for a moment to point out that...

I pause to draw attention to these dates.

I regret I cannot agree.

I feel no qualms about taking sides against these contributions.

De fait, en common law le rôle du juge est prépondérant. La common law, qui est constamment reformulée pour s'adapter à des situations nouvelles, trouve dans le juge son dépositaire et son interprète reconnu ; lui seul est habilité à reconnaitre et à préciser une règle préétablie, mais disséminée dans une multitude d'arrêts, et à mettre en œuvre dans les décisions de justice ce droit naturel immanent.

Un tel pouvoir doit inciter à la prudence. Si le juge ne craint pas de s'engager personnellement il le fait avec la pondération qui sied au reasonable man, notion qui correspond au «bon père de famille » du droit français. On ne sera pas surpris dans ces conditions du recours à la litote et au hedging qui mettent l'énoncé en perspective et suggèrent que le locuteur prend du recul par rapport à l'opinion qu'il avance :

This reference, as it seems to me, isfatal to the submission.

Speaking for myself; I accept the statements...

I, for my part, would regard...

Not without some reluctance I find myself unable to share this view.

I should have been inclined to reject that challenge.

I would allow the appeal.

C'est dans la mesure où le juge a persuadé ses allocutaires de sa sagesse et de son impartialité que l'expression de son moi n'est plus haïssable. L'exercice du pouvoir est bien réel et c'est peut-être pour le dissimuler que les magistrats anglais utilisent tant la litote et les circonlocutions.

\subsection{Le sens de l'humour}

L'humour et l'ironie peuvent s'exercer au détriment des justiciables : The second defendant is now older and the first defendant is now wiser.

Les institutions et les intervenants sont aussi mis en cause :

Caution, otherwise known as the Treasury, would never allow this to happen.

The tender mercies of juries who are unsympathetic towards insurers.

Before saying au revoir if not adieu to his appeal...

Les confrères ne sont pas épargnés car un discours est d'autant plus convaincant qu'il contribue à renforcer le sentiment d'appartenance à la communauté des juristes; lorsqu'un Law Lord parle dans un arrêt de rather delphic words, ne fait-il pas écho à une déclaration de Lord Diplock?

The court may describe what it is doing in tax appeals as interpretation. So did the priestess of the Delphic oracle. 


\subsection{Une langue imagée}

La langue des juges anglais est souvent métaphorique; on peut classer les diverses métaphores relevées dans les arrêts selon les thèmes suivants.

\section{Le sport, les jeux}

The judge is like a referee : he watches the game and counts the points.

The solicitor's remuneration had to be reasonable on an individual basis and not just reasonable on a swings and roundabout basis.

La guerre, les activités violentes

The oral agreement is invoked as a shield and not as a sword.

Extrajudicial confessions have become an important weapon in the prosecution's armoury.

This is a case of industrial espionage in which the airplane is the cloak and the camera the dagger.

Are the minors to be throttled by the straps which bind them to their infants'chair?

La technique et les activités professionnelles

The judicial opinion is a test tube for sociologists and a slide rule for lawyers.

The exception, like so much else in the common law was hammered out of the anvil of pleading.

L'architecture The regulations are made to buttress this cardinal principle.

La nature et les phénomènes naturels

A businessman may do much to regain his position and yet keep on the windy side of the law.

The Serious Fraud Office should not be allowed to get the information they want by a side-wind.

The law has its epochs of ebb and flow. One of the flood seasons is upon us. Let us gather the driftwood and leave the waters pure.

Legal advisers and their clients are thus left to wade through a morass of case law, only to sink into a quicksand of uncertainy.

Le repérage dans l'espace

The parties stepped wholly out of the four corners of the contract.

The parents cannot achieve the same result through the back door.

Rex $v$. Sheridan represents the high watermark of Mr X's forceful submission The defendant changes tack and seeks to claim political asylum.

La religion

I have to confess to having been a reluctant convert to the notion that the words which Parliament has chosen to use in a statute may fall to be modified.

La médecine

The Act of 1975 was enacted to cure the improprieties of the Act of 1963.

Le corps et ses fonctions

The common law has not suffered a menopause and is not past the age of childbearing.

Les vêtements et leurs accessoires

The court should hesitate to pierce the veil of corporate personality.

Throughout the web of the English criminal law one golden thread is always to be seen, that it is the duty of the prosecution to prove the prisoner's guilt.

A judge must not alter the material of which the Act is woven, but he can iron out the creases.

Le monde animal

After all the efforts to make a silkpurse, the concept remains a sow's ear. 
He who seeks to ride the unruly horse of public policy, must be a skilled equestrian.

That would drive a horse and coach through the principle of comity.

\section{discours d'expressions familières qui contrastent avec l'emploi habituel d'un registre} élevé.

I cannot derive any justification for sweeping the line of equity cases under the carpet as though it did not exist.

It does not follow that a receiver and manager must immediately upon appointment seize all the cash in the coffers in the company.

L'emploi de tournures métaphoriques par les juges anglais est trop constant pour être entièrement anodin. Dans la mesure où la justice est rendue au nom du peuple il faut que le magistrat manifeste son appartenance à la communauté sociale qui garantit sa légitimité et qui est à la fois source du pouvoir et destinataire du message. La présence d'expressions imagées tirées de l'univers domestique a pour fonction de montrer l'ancrage de la justice dans la réalité quotidienne. Toutefois, il convient de souligner que ce qui fut jadis un acte de communication avec le plus grand nombre est devenu au fil du temps un exercice de style dans lequel les membres de la profession font assaut d'imagination.

Le langage métaphorique n'est pas seulement ornemental; il est indissociable d'un certain type de raisonnement juridique. La métaphore qui consiste à établir des analogies entre des concepts abstraits et des termes concrets n'est-elle pas à l'image du droit anglais qui consiste à étendre les precedents à des catégories nouvelles avec lesquelles ils entretiennent des rapports analogiques?

\subsection{Pragmatisme et anti-intellectualisme}

Le goût du concret fait partie du génie de la langue anglaise et cela est particulièrement vrai de l'anglais juridique. À titre d'exemple, Lord Denning prétendait ne pas connaître le sens du terme synallagmatic:

A little while ago I heard of a contract being a "synallagmatic" contract. I had never heard of such a contract before.

51 Lorsqu'un magistrat parle des four walls of the transaction, il se réfère à la règle des four corners qui prévoit que l'interprétation des termes d'un contrat ne doit pas prendre en considération des facteurs extérieurs au document.

Les termes imagés et officiellement reconnus sont couramment employés par la profession. On peut citer entre autres :

cooling off period = période de rétractation

egg-shell doctrine (thin-skull doctrine) : cette règle prévoit que l'auteur d'un délit civil voit sa responsabilité engagée même si le préjudice qu'il a causé est dû en partie à la constitution particulièrement fragile de sa victime :

I am satisfied that the Privy Council did not have what are called "thin-skull" cases

in mind. It has always been the common law that a tortfeasor must take his victim as he finds him.

leapfrog procedure: procédure accélérée qui permet à une affaire civile jugée devant la High Court de faire l'objet d'un recours direct devant la House of Lords en court-circuitant la Court of Appeal. 
l'émanation de l'âme d'un pays et de ses particularismes culturels. On retrouve dans les jugements anglais bien des traits que l'on associe volontiers à la civilisation anglaise. La langue du droit est le reflet d'une société et de ses contradictions : l'emploi d'une langue imagée, voire familière, la méfiance envers l'intellectualisme dédaigneux des réalités concrètes témoignent d'un désir de communication avec l'homme de la rue. Pourtant, force est de constater que les archaïsmes et les tics de langage traduisent l'appartenance à un club de happy few. Le jargon juridique existe même s'il est mâtiné par une tonalité humoristique. Le corporatisme est censé exprimer l'indépendance de l'institution juridique par rapport à l'exécutif ; toutefois, ce langage spécifique n'est-il pas aussi un moyen pour une profession de pratiquer un exercice feutré du pouvoir ? C'est de cette ambiguïté que le citoyen doit avoir conscience s'il veut exercer un contrôle éclairé sur la manière dont fonctionne la justice de son pays.

\section{BIBLIOGRAPHIE}

Bosmajian, H. Metaphor and Reason in Judicial Opinions, Carbondale : Southern Illinois University Press, 1992.

Cornu, G. 1990. La linguistique juridique. Paris :Éditions Montchrestien.

Cornu, G. 1990. Vocabulaire juridique, 2e éd. revue et augmentée. Paris : Presses Universitaires de France.

Crystal, D. and D. Davy. 1969. Investigating English Style. Londres : Longman.

Didier, E. 1990. Langues et langages du droit. Montréal : Wilson \& Lafleur.

Fish, S. 1989. Doing What Comes Naturally; Rhetoric in Literary and Legal Studies. Oxford : Clarendon Press.

Garner, B. The Elements of Legal Style, Oxford : Oxford University Press, 1991. 
Gémar, J.-C. 1993. « Fonction de la traduction en milieu bilingue et langage du droit au Canada ». Thèse d'État, Université de Toulouse-le Mirail.

Goodrich, P. 1987. Legal Discourse: Studies in Linguistics, Rhetoric and Legal Analysis. Londres : Macmillan Press.

Kevelson, R. 1988. Law as a System of Signs. New York : Plenum Press.

Klinck, D. 1991. The Word of the Law. Approaches to Legal Discourse. Ottawa : Carleton University Press.

Mimin, P. 1978. Le style des jugements, 4e éd. Paris : Librairie Technique.

Posner, R. A. 1988. Law and Literature. Cambridge, MA. : Harvard University Press.

Solan, L. 1993. The Language of Judges. Chicago : The University of Chicago Press.

Sourioux, J.L. et P. Lerat. 1975. Le langage du droit. Paris : Presses Universitaires de France.

Toussignant, C. 1990. La linguistique en cour de justice. Québec : Presses de l'Université du Québec.

White, J. B. 1985. Heracles'Bow. Madison, WI : University of Wisconsin Press.

\section{RÉSUMÉS}

Par certains aspects, le discours juridique semble ne pas connaître de frontières. En France comme en Angleterre, on constate le fréquent recours à un jargon spécifique ainsi que l'emploi d'un registre élevé. De plus, la langue du droit de ces deux pays tend à donner une acception spécifique à certains mots usuels. Enfin, la présence de termes français rappelle le rôle joué par la conquête normande dans l'élaboration du droit anglais. Toutefois, la spécificité du discours juridique en Angleterre est indéniable : la common law a non seulement élaboré des concepts qui lui sont propres mais elle exprime au moyen d'un discours personnalisé et prolixe et par l'intermédiaire d'une langue imagée l'approche pragmatique d'un système de droit fondé non point sur un code abstrait mais sur un raisonnement inductif. Ainsi, cette langue de spécialité est bien l'émanation de l'âme d'un pays et de ses particularismes culturels.

In some respects legal discourse seems to know no frontiers. In France and in England the use of a specific jargon and of an elaborate style is frequently noticed. Moreover, in both countries the language of the law tends to endow certain ordinary words with a specific acceptation. Finally, the presence of French terms reminds us of the part played by the Norman conquest in the making of English law. Nevertheless, legal discourse in England has its own distinctive features: not only has the common law elaborated its own concepts but it also resorts to a personalized, prolix and metaphorical language in order to express the pragmatic quality of a legal system which is not based on an abstract code but on inductive reasoning. Therefore it can be said that this language for a specific purpose is the expression of the soul of a country and of its cultural identity.

\section{INDEX}

Keywords : analogical reasoning, inductive approach, language of the law, legal English, pragmatism, shift in meaning, common law

Mots-clés : anglais juridique, approche inductive, glissement de sens, langue du droit, pragmatisme, raisonnement analogique, common law 
AUTEUR

BERNARD GALONNIER 